p-ISSN 1693-1246

e-ISSN 2355-3812

June 2020
Jurnal Pendidikan Fisika Indonesia 16 (1) (2020) 41-46

DOI: 10.15294/jpfi.v16i1.23596 http://journal.unnes.ac.id/njulindex.php/jpfi

\title{
The Development of Experimental Absorption Based on Arduino-Uno and Labview on Light Radiation by Colourful Surface
}

\author{
Rahmatullah*, Suparno \\ Postgraduate Physics Education, Universitas Negeri Yogyakarta, Indonesia
}

Received: 28 February 2020. Accepted: 30 March 2020. Published: 30 June 2020

\begin{abstract}
This development research aims to make a tool and test its ability to absorb the heat in light radiation by colored surfaces (black, dark green, blue, white). The benefit of this research is to present a simple laboratory that can be used in physics education class as a test tool for heat absorption. The research method that applied is Microcomputer Based Laboratory (MBL). The software that used is LabVIEW which connected to Arduino Uno hardware and heat source. The appropriate set of tools and materials is then tested for eligibility. The feasibility test of the device is reviewed from the aspect of content, linguistic, presentation and graphic by an expert validator as well as the compatibility of the findings with the theory. The results found that the darker the color of the object, the greater the ability of heat absorption and vice versa. Changes in power at a light source can affect changes in maximum temperature in the color absorption of heat. The greater the power provided by the light source, the greater the increase in maximum temperature. This development research concludes that the tools are feasible to use and appropriate based on existing theories.
\end{abstract}

Keywords: Arduino-Uno; Colored Surfaces; Heat Absorption; LabVIEW; Light Radiation

\section{INTRODUCTION}

Heat is a process of energy transfer due to temperature differences. Daily life is often shrouded in heat from the sun. The sun as the biggest source of heat has many benefits for humans. Humans really enjoy the benefits of solar heat, as well as in various fields of agriculture, even as a source of electricity generation.

In daily activities, everyone must have felt hot. Most people don't know the cause of this phenomenon including students. Most students consider it happens because of the direct sunray or the type of clothes they wear. Even though other causes can make this happen such as the color of the clothes.

A study states that there are big differences between teachers' and students' understanding of the connection between color, temperature, and heat. Canlas (2016) states that his respondents fail to properly track the flow of heat energy from one system to anot-

*Correspondence Address:

Jl. Colombo Nomor 1 Karangmalang, Yogyakarta 55281

E-mail: rahmatismail6@gmail.com her. His respondents also fail to apply it right in their daily life. He found that students consider bright colors like yellow and orange present warmer temperatures, while black and green present cooler ones.

The misunderstood of this concept is of concern to researchers so that it can be corrected. This case can be answered with the solution based on existing physical concepts. Therefore, some lessons that support students in mastering physics completely is needed.

Physics is essentially a collection of knowledge, ways of thinking and inquiry. Physics is not only about a collection of principles, concepts, or facts but also discoveries and prospects for further development. Furthermore, these findings can be applied or utilized in daily life.

Physics emphasizes concepts in learning or understanding. Good and right concepts help students to understand physics easier. Suseno (2014) states that physics has abstract concepts that need to be tested theoretically. The material that contains abstract concepts becomes a significant difficulty for participants. Students have some difficulties in mastering 
existing materials. One of the abstract materials is radiation on heat transfer.

The concept of radiation needs to be emphasized in the practical aspect to prove the material. In fact, in schools, it is still hard to find test tools that can be used to prove the truth about the concept of radiation in physics (Wulandari, et al. 2016). As a result, practical activities as a learning investigation medium cannot be carried out even though it can improve students' understanding of the concepts (Maghfiroh \& Sugianto, 2011).

Puspasari (2017); Saepuzaman \& Yustiandi, (2017) states that practicum tools are needed by educational institutions (schools). Practical tools can support the learning process in the classroom. Teachers can help students' learning performance by using tools such as technology.

Learning in 21st Century emphasizes technology-based activities. The presence of technology is convenience for teachers and students. Moreover, practicum activities combined with media/technology will provide more effectiveness and efficiency in learning. It's work and has been proved by some previous studies that combine computer devices with hardware (Arduino).

The research conducted by Zachariadou, et al., (2012) states that the educational laboratories based on computer technology with the help of Arduino provide convenience at a low cost. The advantage of Arduino-Uno is it doesn't need a programmer chip device. This can happen because there is a bootloader inside of it that will handle program uploads from the computer. Arduino-Uno has a USB communication tool, so laptop users who don't have serial / RS323 ports can use it. The programming language is relatively easy because the Arduino-Uno software is equipped with a fairly complete collection of libraries, it has a readymade module (shield) that can be plugged into the Arduino board. For example, shield GPS, Ethernet, SD Card, and others (Magdalena, et al. 2013).

The software that can be combined with Arduino-Uno in conducting heat absorption tests is LabView. LabVIEW can be used as a human-machine interface (HMI), it is because LabVIEW has program functions that can form an interface that represents several criteria as $\mathrm{HMI}$. These functions include monitoring realtime conditions in the plant, visualizing events or processes that are happening, and it can carry out measurement logging data (Wardoyo, et al. 2013).

Consider the facts above, development research was carried out in order to make an experimental tool to support the physics learning process about the heat transfer material. The tool that was developed based on ArduinoUno and LabVIEW.

\section{METHOD}

This research is an experimental research development. The research method used in the form of Microcomputer Based Laboratory (MBL). The design of the developed instrument can be seen as shown in Figure 1. Research procedures go through several processes, namely the process of making tools and the testing process. The manufacturing process is carried out in several stages including: (a) the stage of making a radiation test box (containing a bulb, colored plate and LM35 temperature sensor), (b) the wiring stage with an LM35 temperature sensor on Arduino-Uno, (c) the stage of making a virtual instrument in the LabVIEW application. This study uses four units LM35 temperature sensor and is affixed to colored surface. The LabVIEW application used is LabVIEW 2014 (64bit). The completed manufacturing steps are then continued towards the integration process so that it becomes a series of heat absorption test equipment.

The series of research schemes that have been developed are then passed the feasibility test and theory-based tests. The feasibility test of the device is reviewed from the aspect of content, linguistic, presentation and graphic by an expert validator. After meeting the eligibility criteria, then proceed to testing in theory in the form of data collection.

Indicators of the success of the device are made such as a good feasibility test based on expert judgment and the ability of the tool to test the effect of color surfaces on heat absorption in light radiation. In addition, this study also took data in the form of the relationship of power variations with the maximum temperature achieved and the difference in time required to reach the maximum temperature.

The instrument feasibility observation data is based on several indicators. After the assessment is obtained then it is converted into the following categories (Sahidu, 2013).

The dependent variable is a different color and different lamp power used. The colors used in the test are black, dark green, blue and white. The dependent variable observed was 
the ability of heat absorption and the maximum temperature that could be achieved by each color. The control variables in this study are room temperature, and the distance of each color to the lamp.

Table 1. Criteria for Assessing the Feasibility of Test Equipment

\begin{tabular}{cc}
\hline Value Conversion & Criteria \\
\hline $90-100$ & Very Good \\
$80-89$ & Good \\
$65-79$ & Moderate \\
$55-64$ & Bad \\
$<55$ & Very Bad \\
\hline
\end{tabular}

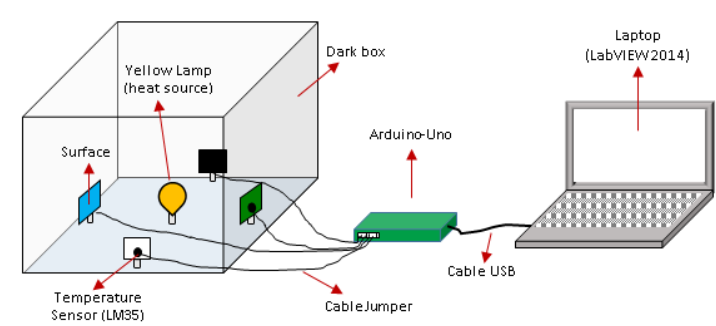

Figure 1. Experiment Scheme

\section{RESULTS AND DISCUSSION}

This research produced a tool that can test the heat absorption of several colors through the help of the LabVIEW application. In addition, the tool developed can also test the relationship of power variations $(P)$ to the maximum temperature $\left(T_{\max }\right)$ on a colored surface.

The way this tool works is very simple. When the application is run and then, the lights are turned on, the temperature sensor will capture radiation by each color used simultaneously. The distance between the lamps and all plates is the same. So, the data obtained is valid. The LabVIEW application will read changes automatically with digital notes and virtual thermometers. The use of LabVIEW and LM35 Sensors are often used in several studies one of which is the Sandeep \& Prakasam research (2019).

Making this tool does not take a long time and how to make it is very simple. The developed instrument is said to be good or can be used because it has passed several series of test processes. Tests carried out such as temperature sensor capability tests, LabVIEW tests, validation of experimental devices, feasibility tests of experimental modules and tests by taking data on the colors used.

\section{LM35 Temperature Sensor Test}

This test is carried out to assess the performance of the temperature sensor used. Arduino-Uno which is connected to LabView and temperature sensors is then run. Based on the temperature data contained in the LabVIEW front panel, it can be seen that the room temperature value is around $30^{\circ} \mathrm{C}$. Subsequent tests using body temperature by touching hands on the LM35 sensor. The result shows that there is a change in temperature to $37^{\circ} \mathrm{C}$ which is visible at the thermometer in the front panel. According to Tansey and Johnson (2014), the normal temperature of the human body is at $37^{\circ} \mathrm{C}$. This means that the LM35 temperature sensor is suitable for use as research material. The excess use of the LM35 temperature sensor is because it has a linear scale of $+10 \mathrm{mV} /{ }^{\circ} \mathrm{C}$ and has a temperature range that can be measured from $-55^{\circ} \mathrm{C}$ to $+150^{\circ} \mathrm{C}$ (Malvika, et al. 2015). When the temperature exceeds the threshold, the output will produce a buzzer.

\section{LabVIEW test}

LabView is useful in facilitating data control and instrumentation developed (Wang, et al. 2012). To be able to communicate with Arduino, LabVIEW requires additional software called VISA (The Virtual Instrument Software Architecture) which is software for configuration, programming, and troubleshooting of instrumentation systems, PXI serial, Ethernet and USB interfaces. VISA provides a programming interface between LabVIEW and Arduino.

LabVIEW testing is carried out in the block diagram section. The block diagram created as shown in Figure 2 consists of four main parts of the program, namely temperature, serial port, channel sensor, and stop button. In each of these sections also contains programs that are representations of the results of measurements made by sensors and have been processed by Arduino. After running, the temperature identification display will appear on the LabVIEW front panel like Figure 3.

\section{Test the validation of experimental tools}

The design and development of tools that have been carried out are then tested for validity by experts. A Validity test uses a questionnaire assessment with several aspects of assessment. The questionnaire was given to the validator consisting of a tool expert lecturer, a media expert lecturer, a laboratory assistant, and two students. The results of these tests are experimental tools in the good category with a 
value of 85 .

According to experts, the design of the tool has been well made. The safety and conditioning of the variables that may affect the measurement have been minimized properly. So, this experimental tool is suitable to be used to test the absorption of light on the radiation of light on a colored surface.

\section{Test the feasibility of the experimental mo- dule}

Every practicum activity requires a practicum instruction module. According to Waluyo \& Parmin (2014), practical instructions play a role the scientific performance and the development of student attitudes. This role requires modules with good criteria and are suitable for use. The module must pass the feasibility test stage to then be used as well as possible. The feasibility test uses several indicators in a questionnaire. The aim is to get an assessment, suggestions, and criticism from experts in order to know the level of feasibility of the modules made. From the results of processing questionnaire, it obtained a value of 82 with a good category and is suitable for use.

According to expert validators, the design of the display modules, fonts, layouts is well arranged and attractive. The grammar used is in accordance with Indonesia dictionary (KBBI). The module content reflects structured practicum guidelines. So that the experimental module is feasible to be used as a guideline for the practical absorption of heat on colored surface light radiation.

\section{Test Data}

Tests carried out directly lead to data retrieval. LM35 sensor that has been tested for its capacity in measuring temperature, is then affixed to a colored plastic plate in a test box. The testing process begins with the initial temperature measurements on each sensor so that they are at the same temperature. Based on the initial test results obtained a room temperature of $30^{\circ} \mathrm{C}$. After uniform temperature in all colors, the $25 \mathrm{~W}$ yellow lamp is turned on and the results in the LabView application are immediately observed. In a simple measurement result every second can be extracted into Microsoft Excel for later analysis and graphs (Figure 4).

Based on observations it was found that each color has a different absorption ability. The black color has a very large absorption compared to other colors (Giancoli, 2001). While the color white has a very small absorption compared to other colors. Dark green has higher absorption than blue and white. The following Table 2 shows the observations seen from the maximum temperature obtained each color. Hardiyanto, et al. (2017) stated that young colors such as white have fewer heat absorption rates, ranging from $10 \%-15 \%$, whereas in old colors like black can absorb heat up to $95 \%$. Research conducted by Stuart-Fox, et al.

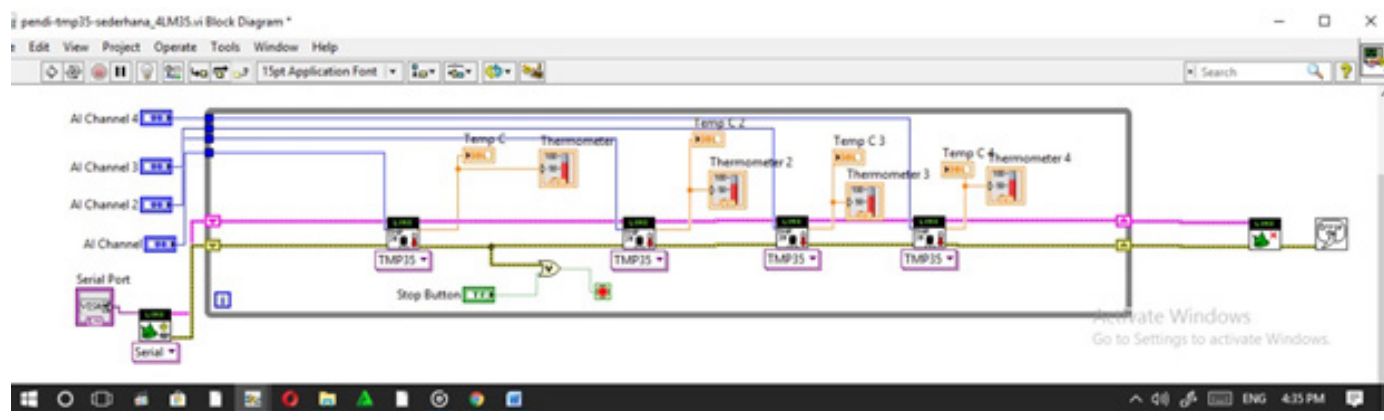

Figure 2. Block Diagram LabVIEW

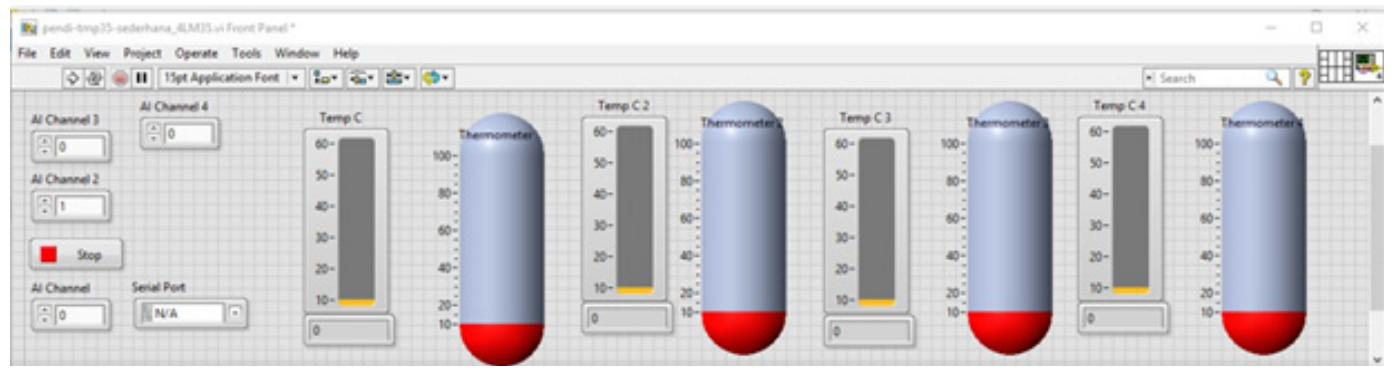

Figure 3. Front Panel LabVIEW 
(2017) revealed that differences in color affect the absorption of heat with dark colors have high heat absorption ability.

Table 2. Maximum Temperature Color of Each Surface with $25 \mathrm{~W}$ Lamp Power

\begin{tabular}{ccc}
\hline Color & Temperature $\left({ }^{\circ} \mathrm{C}\right)$ & Time $(\mathrm{s})$ \\
\hline Black & 41,50 & 285 \\
Dark green & 39,03 & 290 \\
Blue & 38,01 & 300 \\
White & 36,62 & 310 \\
\hline
\end{tabular}

The maximum temperature reached by each color on the plat indicates that each color has a different heat absorption ability. Previous research suggests that the black surface absorbs more heat than the white surface at the same power (radiation source). Each color has a different emissivity value based on the level of darkness of the color. The darker the color, the greater the emissivity (lannacone et al, 2012; Levandovski et al, 2013).

Color heat absorption ability has a time difference. Black is faster in reaching maximum temperatures with a time of 285s. Meanwhile, the color white becomes the longest color reaching a maximum temperature of 310 s. Dark green takes 290s and blue takes 300s.

A large increase in temperature of heat absorption by plastic colors can be seen in Figure 4. The graph shows that there is direct heat absorption by colored plastic. This is evidenced by changes in temperature that occur. Very rapid and extreme temperature increases occur in black. While other colors increase slowly until the maximum value. Temperature changes with time inverse exponentially in all colors. This temperature change over time. The longer the time the slower the increase in temperature to the point where the temperature cannot increase anymore which is called the maximum temperature $\left(T_{\text {max }}\right)$.

When related to existing theories, these results are following form of equation:

$\mathrm{P}_{\mathrm{r}}=\Delta \mathrm{Q} / \Delta \mathrm{t}=\mathrm{e} \sigma \mathrm{AT}^{4}$

where is the radiated power, is the surface area, is a universal constant called the Stefan constant, is temperature and is the object's emissivity, its value varies between 0 and 1 depending on the surface composition of the object (Tipler, 2001).

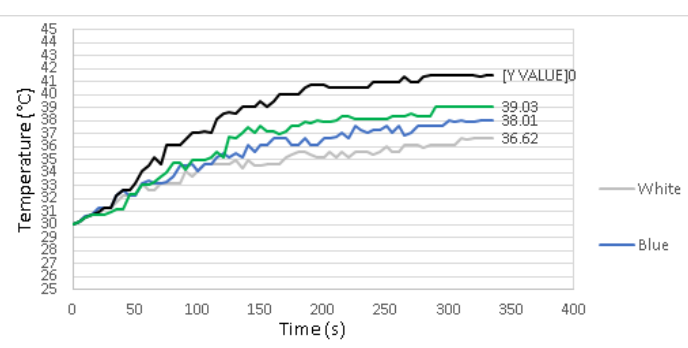

Figure 4. Temperature Increase Graphs on Color Surface with 25W Power.

The next data collection aims to determine the relationship of the addition of power $(P)$ to the maximum temperature of each color. The type of incandescent lamp used is the same. But the power used is different, namely 25watt, 40 watt and 60watt. Adding power will also increase the intensity of the light provided. This means that the light intensity is given more, the change in temperature will be increase. The use of incandescent lamps is due to several reasons including cheap and not much influence on electric voltage compared to fluorescent lamps and the effect on health is better than incandescent fluorescent lamps (Ogrutan, et al. 2016; Monroe, 1999).

The observations found can be seen in Table 3. Based on the table, the temperature change increases when the light source power is increased. This is consistent with the existing theory that the greater the power applied to a colored surface, the maximum temperature will be even greater (Tipler, 2001).

\section{CONCLUSION}

Based on observations and discussions, it can be concluded that the developed instrument can be used well to test the absorption of several colors of heat on plastic and can test the relationship of variations in power to the

Table 3. The Relationship between Power Changes and the Maximum Temperature of Each Color

\begin{tabular}{ccccccccccccc}
\hline \multirow{2}{*}{$\begin{array}{c}\text { Power } \\
\text { (watt) }\end{array}$} & \multicolumn{3}{c}{ Black } & \multicolumn{1}{c}{ Dark Green } & \multicolumn{4}{c}{ Blue } \\
& $\left.\mathrm{T}_{0}{ }^{\circ} \mathrm{C}\right)$ & $\begin{array}{c}\mathrm{T}_{\max } \\
\left({ }^{\circ} \mathrm{C}\right)\end{array}$ & $\begin{array}{c}\Delta \mathrm{T} \\
\left({ }^{\circ} \mathrm{C}\right)\end{array}$ & $\begin{array}{c}\mathrm{T}_{0} \\
\left({ }^{\circ} \mathrm{C}\right)\end{array}$ & $\begin{array}{c}\mathrm{T}_{\max } \\
\left({ }^{\circ} \mathrm{C}\right)\end{array}$ & $\begin{array}{c}\Delta \mathrm{T} \\
\left({ }^{\circ} \mathrm{C}\right)\end{array}$ & $\begin{array}{c}\mathrm{T}_{0} \\
\left({ }^{\circ} \mathrm{C}\right)\end{array}$ & $\begin{array}{c}\mathrm{T}_{\max } \\
\left({ }^{\circ} \mathrm{C}\right)\end{array}$ & $\begin{array}{c}\Delta \mathrm{T} \\
\left({ }^{\circ} \mathrm{C}\right)\end{array}$ & $\begin{array}{c}\mathrm{T}_{0} \\
\left({ }^{\circ} \mathrm{C}\right)\end{array}$ & $\begin{array}{c}\mathrm{T}_{\max } \\
\left({ }^{\circ} \mathrm{C}\right)\end{array}$ & $\begin{array}{c}\Delta \mathrm{T} \\
\left({ }^{\circ} \mathrm{C}\right)\end{array}$ \\
\hline 25 & 29,98 & 41,50 & 11,52 & 29,88 & 39,03 & 9,15 & 29,93 & 38,01 & 8,08 & 29,95 & 36,62 & 6,67 \\
40 & 30,01 & 43,72 & 13,71 & 29,89 & 40,35 & 10,46 & 30,03 & 39,54 & 9,51 & 29,98 & 37,23 & 7,25 \\
60 & 29,96 & 46,15 & 16,19 & 30,03 & 42,13 & 12,10 & 30,01 & 40,78 & 10,77 & 29,91 & 39,12 & 9,21 \\
\hline
\end{tabular}


maximum temperature produced. Black absorbs heat faster than dark green, blue, and white. White has the weakest absorption capacity of the heat compared to other colors. The older a color is, the stronger its heat absorption ability, and brighter the color, the smaller its heat absorption ability. The greater variation in power causes the maximum temperature in the heat absorption of each color to increase. The researcher suggests that the education element can make or use the development of this experiment for the benefit of students in order to achieve learning objectives. Further research is expected to get more information about some of the findings in the development of this experiment.

\section{REFERENCES}

Canlas, I.P. (2016). Color, Temperature and Heat: Exploring University Students Mental Thoughts. Universal Journal of Educational Research. 4(1): 72-75. DOI:10.13189/ujer.2016.040109

Giancoli, C.D., (2001) FISIKA (edisi kelima). Jakarta: Erlangga.

Hardiyanto, A., Aji, M.P., \& Yulianto, A. (2017). Pelapis Pemantul Panas menggunakan Senyawa $\mathrm{TiO}_{2}$. Unnes Physics Journal. 6(1), 70-73.

lannacone, M.R., Wang, W., Stockwell, H.G., O'Rourke, K., Giuliano, A.R., Sondak, V.K., Messina, J.L., Roetzheim, R.G., Cherpelis, B.S., Fenske, N.A. \& Rollison, D.E. (2012). Patterns and timing of sunlight exposure and risk of basal cell and squamous cell carcinomas of the skin - a case-control study, BMC Cancer, 12, 1-11.

Levandovski, R., Pfaffenseller, B., Carissimi, A., Gama, C.S. \& Hidalgo, M.P.L. (2013). The effect of sunlight exposure on interleukin-6 levels in depressive and non-depressive subjects. BMC Psychiatry. 13, 1-8.

Magdalena, G., Aribowo, A., \& Halim, F. (2013). Perancangan Sistem Akses Pintu Garasi Otomatis. Proceedings Conference on Smart-Green Technology in Electrical and Information System, pp: 301-205

Maghfiroh, U., \& Sugianto. (2011). Penerapan Pembelajaran Fisika Bervisi Sets Untuk Meningkatkan Kemampuan Berpikir Analitis Peserta Didik Kelas X. Jurnal Pendidikan Fisika Indonesia. 7(1), 6-12.

Malvika, D.M., Sandhya, K.S. Akshay, S. (2015). Control of the Locomotion of Temperature Sensor. International Journal of Applied Engineering Research. 10(6), 14405-14419.

Monroe. (1999). Electric Light. World Book, Chicago. Ogrutan, P., Aciu, L.E., Sandu, F., \& Gerigan, C. (2016). Student Active Participation in the Study of the Light Bulbs. TEM Joournal. 5(4), 424-434. https://dx.doi.org/10.18421/
TEM54-03

Puspasari, R. (2017). Implementasi Project Based Learning Untuk Meningkatkan Kemandirian Dan Prestasi Belajar Mahasiswa Dalam Pembuatan Alat Peraga Matematika Inovatif. Math Didactic: Jurnal Pendidikan Matematika, 3(1): 10-22.

Saepuzaman, D., \& Yustiandi. (2017). Pengembangan Alat Peraga dan Lembar Kerja Percobaan Penentuan Koefisien Restitusi untuk Meningkatkan Kemampuan Siswa Bereksperimen. Jurnal Penelitian \& Pengembangan Pendidikan Fisika, 3(2): 145-150. https://doi.org/10.21009/1.03204

Sahidu, H. 2013. Penilaian Hasil Belajar. Mataram: Arga Puji Press.

Sandeep, P., \& Prakasam, V. 2019. LM35 Temperature Sensore Using LabVIEW NI myDAQ. International Journal of Innovative Technology and Exploring Engineering (IJITEE). 9(1), 3073-3077.

Stuart-Fox, D, Newton, E \& Clusella-Trullas, S. (2017). Thermal consequences of colour and near-infrared reflectance. Philos Trans $R$ Soc Lond B Biol Sci. 372, 1-8. https://doi:10.1098/ rstb.2016.0345

Suseno, N. (2014). Pemetaan Analogi Pada Konsep Abstrak Fisika. Jurnal Pendidikan Fisika. 2(2): 1-10.

Tansey, E.A., \& Johnson, C.D. (2015). Recent advances in thermoregulation. Adv Physiol Educ. 39: 139-148. http://doi:10.1152/advan.00126.2014

Tipler, P.A. (2001). Fisika untuk Sains dan Teknik Edisi Ketiga Jilid 2, diterjemahkan oleh Bambang Soegijono, Jakarta: Erlangga.

Waluyo, M.E., \& Parmin. (2014). Pengembangan Panduan Praktikum IPA Terpadu Berbasis Inkuiri Terbimbing Tema Fotosintesis Untuk Menumbuhkan Keterampilan Kerja IImiah Siswa SMP. Unnes Science Education Journal. 3(3), 677-684.

Wang, L., Tan, Y., Cui, X., \& Cui, H. (2012). “The application of LabVIEW in data acquisition system of solar absorption refrigerator" Energy Procedia. 16(C), 1496 - 1502.

Wardoyo, S., Munarto, R., \& Putra, V.P. (2013). Rancang Bangun Data logger suhu menggunakan labview. Jurnal IImiah Elite Elektro. 4(1): 23-30.

Wulandari, R., Susilo, H., \& Kuswandi, D. (2016). Multimedia Interaktif Bermuatan Game Edukasi Sebagai Salah Satu Alternatif Pembelajaran IPA Di Sekolah Dasar. Jurnal Pendidikan. 2: 1-8.

Zachariadou, K., Yiasemides, K., \& Trougkakos, N. (2012). A low-cost computer-controlled Arduino-based educational laboratory system for teaching the fundamentals of photovoltaic cells. EUROPEAN JOURNAL OF PHYSICS. 33 (2012) 1599-1610 http://dx.doi. org/10.1088/0143-0807/33/6/1599 